\title{
Supraglottic Cancer pT2 TNM Finding v8
}

National Cancer Institute

\section{Source}

National Cancer Institute. Supraglottic Cancer PT 2 TNM Finding v8. NCI Thesaurus. Code C133103.

Supraglottic cancer with tumor invading the mucosa of more than one adjacent subsite of supraglottis or glottis or region outside the supraglottis (e.g., mucosa of base of the tongue, vallecula, medial wall of pyriform sinus) without fixation of the larynx. (from AJCC 8th Ed.) 